\title{
Self - Employment Among Youths in Ojo and Alimosho LGA, Lagos Nigeria: Perceptions, Attitude and Contributions - A Statistical Assessment
}

\author{
Emmanuel M. ${ }^{1 *}$ Ikegwu $\quad$ Olakunle D. ${ }^{2}$ Ogunjirin $\quad$ Ademola A. ${ }^{1}$ Fadiji $\quad$ Adekunle A. ${ }^{1}$ Ayodeji \\ 1.Department of Statistics, Yaba College of Technology, Yaba, Lagos Nigeria \\ 2.Department of Social Sciences, Yaba College of Technology, Yaba, Lagos Nigeria
}

\begin{abstract}
This study examined the perceptions, attitude and contribution of self - employment among youths in Lagos State with the aim of ascertaining the factors that inspire perception, attitude of youth self-employment and how it impacts the youths. A survey was conducted among youths in Ojo LGA, Lagos State Nigeria using a self - designed questionnaire collect data on different factors related to youth perception, attitude and contributions to selfemployment. Data collected was analysed using descriptive statistic, Chi Square test and Analysis of Variance with the aid of Statistical Packages for Social Science (SPSS). The result show that $57.0 \%$ of the youths agreed that self-employment development among young people is high and this was significantly associated with perception and attitude of self-employed youth $(\mathrm{p}<0.05)$. However, the perception, attitudes and views on contribution of self - employment differed significantly among youths from the major ethnic nationalities in Nigeria $(p<0.05)$. It was therefore concluded that some demographic factors are significantly associated with perception and attitude of youths on self-employment. Also, self - employment improves the standard of living of youths and increase national income while lack of conducive business environment, high cost of doing business and lack of strong and consistent patent - law was among the factors that significantly negatively impact self employment drive in the country. The study recommended that the government should create a conducive business environment and work towards reduction of the high cost of doing business as a way of encouraging youths into self - employment.
\end{abstract}

Keywords: Self - employment, perception, contribution, standard of living, youths

DOI: $10.7176 / \mathrm{JPID} / 51-05$

Publication date: November $30^{\text {th }} 2019$

\section{Introduction}

The promotion of entrepreneurship as a possible source of job creation, empowerment and economic dynamism in a rapidly globalised world has attracted increasing policy and intellectual attention in recent years (Lindh, 2017; Pollard \& Wilson, 2013; Reid \& Ferguson, 2011). The loss of jobs, global economic downturn that made many businesses fail resulting in downsizing and other tough management decisions has made entrepreneurial spirit an alternate to paid employment (corporate or public). However, despite the attention generated, youth unemployment is steadily rising. There has been no systematic attempt to find the balance between the education of the young people and their entrepreneurial spirit (mindset) in addressing the problem of youth unemployment. Youth self - employment is a fairly new yet growing field in the world of development programs. As World Youth Report (2012) noted that youth self-employment is not for everyone and so cannot be viewed as a large-scale solution to the youth employment crisis. Nonetheless, there is a growing interest in the provision of micro-finance for youth because it is recognised that education and training on their own do not usually lead to a sustainable selfemployment.

Youth is often considered as a stage where childhood transits into adulthood and it is the transition from being dependent to being independent (World Youth Report, 2012). One of the most critical factors is the employment status and most young people often feel that having a job or means of livelihood would give them sense of independence which could give them the ability to make choice about their lives, families as well as peers. This has resulted in the lack of an adequate understanding of the potential benefit of youth enterprise as a means of improving youth livelihood (World youth report, 2012). The concept of youth has been understood and used differently by different government, non-governmental organisations and the public in general (Mkandawire, 1996). The United Nations to described youth as those in ages 15-24 years while the Common Wealth Association of Nations categorised youth as those within ages of $15-29$ years. Most countries have either adopted the UN or Common Wealth while in Nigeria adopted ages 18 - 35 years as youths (Kigbu, 2007).

Unemployment occurs when people are without jobs and they have actively sought for job within the past four weeks (ILO, 2007). Fajana (2004) refers to unemployment as a situation where people who are willing and capable of working are unable to find suitable paid employment. It is also defined as a situation in which people who are willing to work at the prevailing wage rate are unable to find jobs (Patterson, 2006). Unemployment is one of the macro-economic problems which every responsible government is expected to monitor and regulate as 
the higher the unemployment rate in an economy the higher would be the poverty level and associated welfare challenges. One of the major challenges facing government today is the reduction of youth unemployment as many do not have jobs due to lack of relevant competency needed to attain available job positions (Ulrich, 2006). The National Bureau of Statistics (2011) in a survey report noted that the country's unemployment rate increased to $23.9 \%$ in 2011 compared to the $19.7 \%$ in 2009 and 2010. and was higher in rural areas $(25.6 \%)$ than in urban areas $(17.1 \%)$.

Nigeria, like all other developing countries aligns with growing global interest in self - employment as a source of economic growth because of high and rising unemployment levels, and festering high poverty levels. This has shifted government's focus to supporting Small and Medium Enterprises (SME) to create employment opportunities as evident in the restructuring of Bank of Industry (BOI) to ensure a regulatory framework for all enterprises of all types and sizes, promote growth, employment, innovation, stability, good governance, confidence and international competitiveness (Idris, 2015; Abdul-Kemi, 2014).

According to the former minister of trade and investment, Aganga (2013), the university entrepreneurship development programme (UNEDEP) was embarked upon to promote self-employment among the youth right from higher institutions of learning as part of the government's proactive approaches to tackle graduate joblessness. The scheme was to provide a mentoring platform for students, reduce poverty and re-orientate undergraduates toward the right values and provide them opportunity to acquire practical experience to aid them manage successfully their own businesses. The UNEDEP's mission was to 'catch them young' and was aimed to create future entrepreneurs and encourage self-employment and thereby reduce poverty (Aganga, 2013). This is because promoting the culture of self - employment among the young people through nurturing and unearthing talents will stimulate economic growth and development within a country and reduce unemployment rate which according to the Nigerian Bureau of Statistics rose from 12.1\% Q1 2016 to 13.9\% in Q4 of same year as graduates find it difficult to secure job (Tijani, 2016). The shift towards self - employment as a means of creating jobs rather than seeking formal employment through the development of entrepreneurial attitudes and mindset among our graduates will advance job creation initiatives and will be very critical towards strengthening the battle against crime, hopelessness and poverty. The youths are developing a positive attitude toward self -employment and are willing to make it work for them despite the many challenges they face. A report conducted by Youth Think (2016) showed that youths in East Africa are turning to self - employment, due lack of educational qualification, proper working skills and social exclusion and are committed to developing their skills, and are positively perceptive of self-employment. The report also showed that the youths recognise the skills gap between education and employment and are taking the necessary steps to advance self - employment.

Even though Lagos State has the largest economy in West Africa and Africa's $7^{\text {th }}$ largest economy, entrepreneurs still fall far short of the economic and social progress required to impact the well - being of the of an average self-employed person given that over one-third of the population live below one dollar a day (Oladele, 2013). Because of its large population put between 17.5 and 22.5 million according to Nigeria Population Reference Bureau (2017), Lagos State remains off-track in achieving the Millennium Development Goals (MGDs) including the goal of having low number of people who live in poverty. Doing business in Lagos State is hampered by poor access to fund, infrastructure, poor means of transportation, insecurity of lives and property, political instability and unreliable and poor supply of electricity which all distort the business climate.

\subsection{Self - Employment}

Self - employment is a situation where an individual creates, begins and takes control of the business decision rather than working for an employer. It is the act of working for oneself i.e. carrying on one's own business rather than working for an employer (Abdulkareem, 2012; Citizen Information, 2014). According to (Wikipedia, 2014), self-employment is the act of generating one's income directly from customers, clients or other organisations as opposed to being an employee of a business or person. This implies that self - employment is a situation in which an individual generates his own income instead of being paid salary or wages. With the high rate of unemployment prevailing today, there is need to device strategies to empower individuals for self-employment.

Unemployment is a situation in which people who are capable of working on wage employment or selfengagement, and who are qualified by age to work legally cannot secure employment (Longe, 2017; AbefeBalogun \& Nwankpa, 2012). Available figures from the NBS put the current youth unemployment at a $25 \%$ which implies that about 25 million of Nigeria's youth population per 100 million are unemployed. Eroke (2014) estimated that about two million graduates enter the labour market every year with extremely limited opportunities for employment.

Acquisition of special and relevant skills and creation of jobs have remained a focal point in the Nigerian Government policy overtime, with various initiatives to promote self-dependence and self-reliance in the generation of gainful self-employment. Prince (2016) observed that no fewer than 5,700 youths, drawn from across Lagos State were beneficiaries of trainings and employment programmes bordering on agricultural business, manufacturing, internet business, exporting, tourism among others in 2016. 


\subsection{Perception of Self - Employment}

Edelman \& Yli-Renko (2010) argued that perceptions and other mental features play a fundamental role in both the creation views and discovery of self - employment. In the discovery perspective, cognition has an impact on the chance that some people will identify and seize the opportunity, and prospect identification depends on previous consciousness and knowledge, while exploitation is consequent on having the essential competences. It is further argued that entrepreneurs who recognise opportunities are those capable of reading and recognising patterns, start off businesses and creating jobs for others. These rise to challenge the status quo through the acquisition and development of skills to become producers and job creators. Such persons see the problems in the country as opportunity to create jobs and be self-employed. They provide useful solutions through diverse innovations to the socio-economic problems prevalent. Sola (2016) pointed that examples abound of graduates making the most of the skills they acquired to earn in school and out - of school to make a living and create jobs for others, rather than wasting in the wait for non - existent job.

The future of young people in Nigeria today goes beyond their education but revolve around their their ability to be entrepreneurial, enterprising and recognise and seize opportunity to be create employment opportunities for them. Therefore, young people leaving formal education fully aware of their innate and exterior capabilities, creativity and develop and communicate same in their society. According to Somefun (2014), the personal imperative for self-employment is like the ancient African proverb which opined that "Tomorrow belongs to those who prepare for it".

Entrepreneurship and self-employment are sources of new jobs and economic dynamism in developed countries, and can improve youth livelihoods and economic independence in developing countries. For young people in the informal economy, micro entrepreneurism is a bottom-up method for generating income, self-reliance and a new innovative path to earning a living and caring for oneself (Ulrich, 2006).

\subsection{Attitude towards Self - Employment}

An attitude according to McKenzie-Brown (2012) is "a complex mental state involving beliefs, feelings, values, and dispositions to act in certain ways". Attitudes tend to change across time and situations through an interactive process with the environment, and can offer a prediction about a person's future actions (Carlson, 2001). The work of Robinson, Stimpson, Huefner, \& Hunt (1991) was one of the first to use an attitudinal scale to predict entrepreneurial activity. They used the Entrepreneurial Attitude Orientation (EAO) scale to measure entrepreneurial attitudes based on the constructs of achievement, innovation, personal control and self-esteem. According to Robinson, et al. (1991), achievement in business refers to concrete results associated with the start of a business; personal control of business outcomes concerns one's perception of control or influence over his or her business; innovation in business relates to acting on business activities in novel ways; and perceived selfesteem in business relates to self-confidence with regard to one's business affairs. Research advocates that the success of self - employment as a process can be highly attributed to attitudes towards this process. Attitudes play a critical role in shaping innovation and behaviour of individuals. Self - employment attitudes is defined as attitude towards entrepreneurship as the extent to which people think there are good opportunities for starting a business (Mijoč, Stanić, \& Horvat, 2016; Bosma \& Levie, 2012). Attitudes is very significant in establishing self employment activity within a population and the attitudes relevant includes willingness to bear the level of risk that individuals might be willing to bear and individuals' perceptions of their own skills, knowledge, and experience in business creation (Przepiorka, 2017; Munk, 2016; Simoes, Moreira, \& Crespo, 2013; Bosma \& Levie, 2012).

Oguninola (2011) in the study of Informal Self-Employment and Poverty Alleviation using descriptive analysis and OLS technique in two major cities in Nigeria concluded that the informal sector is a high employer of young school leavers with $86 \%$ of the participants earn above the minimum wage level. Okafor (2011) citing a national survey jointly sponsored by NUC and the Education Trust Fund (ETF) in 2004 to determine the labour market needs; revealed that $44 \%$ of the 20 organisations rated Nigerian science graduates as average in competence, $56 \%$ rated them as average in innovation, half rated them average in rational judgment, $63 \%$ as average in leadership skills and $44 \%$ as average in creativity. However, on needed skills like literacy, oral communication, information technology, entrepreneurship, analytical, problem-solving and decision making, $60 \%$ rated them poor. These statistics echo a poor assessment of Nigerian university graduates and further buttressed the argument that Nigerian university graduates are unemployable.

In this light. the purpose of this study includes to understand the perception and attitude of youth to self employment, measure the proportion of youths engaged in self - employment, identify the environmental factors influencing individual self - employment spirit, identify problems of self - employment among youths in Lagos State and suggest possible solutions and lastly identify the roles of entrepreneurs towards the development of Lagos State. The study would serve as a reference library to so many youth marketing their quest for further investigation on how to become successfully self-employed, reveal the inherent benefits of being self-employed, promote creativity and drive innovation and help youths make informed decisions and generate great investment 
potentials, enable government to coordinate, manage and control the activities of the SMEs and help make funds available for loan to potential self-employed youth thereby impacting positively and greatly on the economy.

\section{Methodology}

The study adopted the investigative survey method that explores youth perception and attitude towards self employment in Lagos State. The population consisted of youths selected from Ojo and Alimosho Local Government Areas in Lagos State. Primary data was collected from the selected youths with the aid a questionnaire designed by the researchers, validated by the researchers in conjunction with other experts and gave a reliability coefficient of ... Simple random sampling was used in selecting the Ojo and Alimosho Local Government Areas in Lagos State, while purposive sample was used to select 351 youths both LGAs. The collected data were analysed using descriptive statistics like frequency distribution, Chi-square was used to measure the association between the perception and attitude of youth self - employment in Lagos State with the aid of Statistical Package for Social Sciences (SPSS 23).

\section{Results}

\section{Table 1: Demographic characteristics of the respondents}

The demographic characteristics of the youths shows that $38.2 \%$ of them were between $15-19$ years, $31.3 \%$ were between 20 - 24 years, $12.3 \%$ between 25 - 29 years and $18.5 \%$ were 30 years and above. Also, 54.7\% of the youths were males, $38.2 \%$ of them have SSCE, while $61.8 \%$ had at least a tertiary experience. In addition, $42.5 \%$ of the youths are Muslims, 48.4\% Christians, 6.3\% Traditional worshippers and 2.8\% practiced other religions. Furthermore, $37.6 \%$ of the youths were Yorubas, $18.5 \%$ were Hausas, $16.0 \%$ Igbos and $27.9 \%$ were from other tribes.

Lastly, only $57.0 \%$ of the youths agreed that self - employment development among young people is high and agreed with the findings of Ogunrinola (2011) who found 55\% owner operators in his study and was slightly higher than the 50\% observed in Statistics Sweden (2006 cited in Bjuggren, Johansson, \& Stenkula, 2010) and significantly higher that $42 \%$ found by Margolis (2014) in developing countries including some selected Sub Saharan African countries. Fields (2014) reported that 53\% of workers in low - income countries are self employed which is still in the region of our finding in this study while Banerjee \& Duflo (2011) reported over $60 \%$ in Sub - Saharan Africa and $80 \%$ in India.

Table 1: Youths perceptions on self - employment

\begin{tabular}{|l|c|c|c|c|c|}
\hline Items & SA (\%) & A (\%) & U (\%) & D (\%) & SD (\%) \\
\hline $\begin{array}{l}\text { There is opportunity for self - } \\
\text { employment in Nigeria }\end{array}$ & $209(59.5)$ & $114(32.5)$ & $8(2.3)$ & $20(5.7)$ & - \\
\hline $\begin{array}{l}\text { The only means of getting truly rich is } \\
\text { through self-employment }\end{array}$ & $148(42.2)$ & $138(39.3)$ & $24(6.8)$ & $37(10.5)$ & $4(1.1)$ \\
\hline $\begin{array}{l}\text { Being self-employed enables you to } \\
\text { have comfort of life }\end{array}$ & $171(48.7)$ & $118(33.6)$ & $31(8.8)$ & $23(6.6)$ & $8(2.3)$ \\
\hline $\begin{array}{l}\text { The only way out of Nigeria's economic } \\
\text { jam is through self-employment }\end{array}$ & $162(46.2)$ & $94(26.8)$ & $20(5.7)$ & $34(9.7)$ & $41(11.7)$ \\
\hline
\end{tabular}

$S A$ - Strongly agreed, $A$ - agreed, $U$-undecided, D-disagreed \& SD - strongly agreed

Table 1 shows that $92 \%$ of the youths agreed that there is opportunity for self - employment in Nigeria, $81.5 \%$ agreed that the only means of getting truly rich is through self - employment, $82.5 \%$ agreed that being self employed enables one to have the comforts of life and $73 \%$ of them agreed that the only way out of Nigeria's economic jam is through self - employment. These results agreed the findings of Margolis (2014) that self employment increases personal income leading to true riches and creates greater independence that leads comfortable life. The results also aligned with Edelman \& Yli-Renko (2010) that for self - employment to thrive, there should be customer demand and ability to compete which are opportunities available in Lagos as enunciated by the youths.

Table 2: Youths attitude towards self - employment

\begin{tabular}{|l|l|l|l|l|c|}
\hline Items & SA (\%) & A (\%) & U (\%) & D (\%) & SD (\%) \\
\hline I recognise opportunity when I see one & $216(61.5)$ & $106(30.2)$ & $14(4.0)$ & $12(3.4)$ & $3(0.9)$ \\
\hline I can generate marketable ideas on my own & $171(48.7)$ & $143(40.7)$ & $11(3.1)$ & $13(3.7)$ & $13(3.7)$ \\
\hline I can take calculated risk & $142(40.5)$ & $105(29.9)$ & $44(12.5)$ & $33(9.4)$ & $27(7.7)$ \\
\hline
\end{tabular}

$S A$ - Strongly agreed, $A$ - agreed, $U$-undecided, $D$ - disagreed \& SD-strongly agreed

Table 2 shows that $91.7 \%$ of the youths agreed that they recognise opportunities when they see one, $89.4 \%$ of them agreed that they can generate marketable ideas on their own and $70.4 \%$ agreed that they can take calculated risk. These results agree with the findings of Neneh (2012) that $88.2 \%$ of entrepreneurs are creative minded, $92.3 \%$ motivated by opportunities while $69.2 \%$ had risk taking propensity. This result also aligned with Pollard \& Wilson 
(2013) who noted that youth entrepreneurs should conceptualise, develop new ideas, formulate creative schemes and ideas. Other studies also confirmed that willingness to take risk positively influences the likelihood of engaging in self - employment (Brown, Dietrich, Ortiz-Nuñez, \& Taylor, 2011). Generally, it was agreed that attitude significantly impacts youths' intentions to be self - employed (Mijoč, Stanić, \& Horvat, 2016).

Table 3: Contributions of self - employed youths to the development of Lagos State economy

\begin{tabular}{|l|c|c|c|c|c|}
\hline Items & SA (\%) & A (\%) & U (\%) & D (\%) & SD (\%) \\
\hline Self - employment development provides job & $193(55.1)$ & $142(40.6)$ & $4(1.1)$ & $8(2.3)$ & $3(0.9)$ \\
\hline $\begin{array}{l}\text { Improvement in standard of living is enhanced } \\
\text { through self-employment }\end{array}$ & $152(43.3)$ & $149(42.5)$ & $26(7.4)$ & $17(4.8)$ & $7(2.0)$ \\
\hline $\begin{array}{l}\text { Increase in national income is a contribution of } \\
\text { self-employed youths to economic growth }\end{array}$ & $179(51.0)$ & $88(25.1)$ & $33(9.4)$ & $26(7.4)$ & $23(6.6)$ \\
\hline
\end{tabular}

$S A$ - Strongly agreed, $A$ - agreed, $U$-undecided, $D$ - disagreed \& SD-strongly agreed

Table 3 shows that $95.6 \%$ of the youths agreed that self - employment development provides job, $85.8 \%$ of them agreed that improvement in standard of living is enhanced through self - employment and $76.1 \%$ agreed that increase in national income is one of the contributions of self - employed youths to economic growth. The results here agreed with Margolis (2014) that self - employment increases personal income and therefore will improve one's standard of living. Somefun (2014) in his discourse submitted that self - employment must be given an imperative place if the nation must revitalise its economy and reduce the choking high rate of unemployment which is in agreement with the assertion of the youths and that of other studies (Ogunrinola, 2011). This implies that self - employment increases local, regional and national income, reduce unempliyment through job provision and improve the standard of living of the citizens by lifting them out of poverty (Tsvetkova, Partridge, \& Betz, 2016; Fields, 2014; Goetz \& Rupasingha, 2013; Bashir, Gebremedhin, \& Fletcher, 2011)

Table 4: Challenges of self - employment development in Lagos State

\begin{tabular}{|l|c|c|c|c|c|}
\hline Items & SA (\%) & $\mathbf{A ~ ( \% )}$ & $\mathbf{U}(\mathbf{\%})$ & $\mathbf{D ~ ( \% )}$ & SD (\%) \\
\hline Lack of strong patent law & $213(60.7)$ & $90(25.6)$ & $19(5.4)$ & $25(7.1)$ & $4(1.1)$ \\
\hline High cost of doing business & $140(39.9)$ & $165(47.0)$ & $18(5.1)$ & $21(6.0)$ & $7(2.0)$ \\
\hline $\begin{array}{l}\text { Lack of knowledge of entrepreneurship in the } \\
\text { basic science and technology }\end{array}$ & $146(41.6)$ & $110(31.3)$ & $45(12.8)$ & $39(11.1)$ & $11(3.1)$ \\
\hline Lack of patronage of local product & $161(45.9)$ & $129(36.8)$ & $17(4.8)$ & $30(8.5)$ & $14(4.0)$ \\
\hline Lack of conducive environment & $145(41.3)$ & $127(36.2)$ & $30(8.5)$ & $18(5.1)$ & $31(8.8)$ \\
\hline Lack of constant power supply & $176(50.1)$ & $88(25.1)$ & $15(4.3)$ & $10(2.8)$ & $62(17.7)$ \\
\hline
\end{tabular}

$S A$ - Strongly agreed, A-agreed, U-undecided, D-disagreed \& SD - strongly agreed

Table 4 shows that $86.3 \%$ of the youths agreed that lack of strong patent law is a challenge to self - employed development, high cost of doing business $(88.9 \%)$, and lack of knowledge of entrepreneurship in the basic science and technology (72.9\%). Also, other challenges to self - employment include lack of patronage of local products (92.7\%), lack of conducive environment (77.5\%) and lack of constant power supply (75.2\%). Okafor (2011) in his discourse concluded that Nigeria investment climate is not investor friendly which was in line with the articulation of the youths that business environment if not conducive. Also, energy crises in Nigeria coupled with high and multiple levies and taxes have combined to make the cost of doing business very excessive. The unavailability or inadequate enterpreneurial know - how due to outdated curriculum in the country and our national unwillingness to step up from policies that do not work were also highlighted by Okafor (2011).

\subsection{Hypothesis Testing}

$\mathrm{H}_{0}$ : Perception, attitude and contribution of self - employment is not significant associated with perceived extent of self - employment development 
Table 5: Relationship between perception of self-employment and extent of self - employment development

\begin{tabular}{|c|c|c|c|}
\hline Concepts & $\chi^{2}$ value & df & $\mathbf{P}$ \\
\hline \multicolumn{4}{|l|}{ Perception on self-employment } \\
\hline There is opportunity for self - employment in Nigeria & 5.126 & 3 & 0.163 \\
\hline The only means of getting truly rich is through self-employment & 7.776 & 4 & 0.100 \\
\hline Being self-employed enable you to have comfort of life & 9.719 & 4 & $0.045 *$ \\
\hline The way out of Nigeria's economic logjam is through self-employment & 1.858 & 4 & 0.762 \\
\hline \multicolumn{4}{|l|}{ Attitude towards self - employment } \\
\hline I recognise opportunity when I see one & 2.010 & 4 & 0.734 \\
\hline I can generate marketable ideas on my own & 6.373 & 4 & 0.173 \\
\hline I can take calculated risk & 10.123 & 4 & 0.038* \\
\hline \multicolumn{4}{|l|}{ Contributions of self-employed youths } \\
\hline Self - employment development provides job & 6.466 & 4 & 0.167 \\
\hline Improvement in standard of living is enhanced through self-employment & 14.305 & 4 & $0.006 *$ \\
\hline $\begin{array}{l}\text { Increase in national income is one of the contributions of self-employed youth to } \\
\text { economic growth }\end{array}$ & 15.592 & 4 & $0.004 *$ \\
\hline \multicolumn{4}{|l|}{ Challenges of self-employment development } \\
\hline Lack of strong patent law is a challenge to self-employment development & 10.018 & 4 & $0.040 *$ \\
\hline High cost of doing business & 24.147 & 4 & $0.000 *$ \\
\hline $\begin{array}{l}\text { Lack of knowledge of entrepreneurship in the basic science and technology are } \\
\text { the challenges to self-employed development }\end{array}$ & 8.395 & 4 & 0.078 \\
\hline Lack of patronage & 3.025 & 4 & 0.554 \\
\hline Lack of conducive environment & 15.902 & 4 & 0.003* \\
\hline Lack of constant power supply & 8.931 & 4 & 0.063 \\
\hline
\end{tabular}

Table 5 shows chi-square analysis of the association between perception of self-employment and the extent of self - employment development and reveals that only being self-employed enables one to have the comforts of life is significantly associated with extent of self - employment development $(\mathrm{p}<0.05)$. Also, a chi-square analysis of the association between attitude to self - employment the extent of self - employment development and reveals only taking calculated risks is significantly associated with the extent of self - employment development $(p<0.05)$. Furthermore, chi-square analysis of the association between contributions of self-employed youths and the extent of self - employment development and reveals that all the contributions except self - employment development provides jobs are significantly associated with extent of self - employment development $(\mathrm{p}<0.05)$. Lastly, a chisquare analysis of the association between challenges of self - employment development and the extent of self employment development reveals high cost of doing business and lack of conducive environment significantly impact on the extent of self - employment development $(\mathrm{p}<0.05)$. These results agreed with (Wioeniewska, Tarczyñska, \& Papiashvili (2015) that most self - employment concepts are not associated with extent of self employment development. The result shows that only the promise of comfort from self-employment is associated with the development of self employment and this aligned with the submission of Szaban \& Skrzek-Lubasińska (2018) about completely independent self-employed who work for the customers of their own choice, when they want, often also how and where they want, without any formal supervision. It was found that risk taking is an attitude that significant affect the development of self - employment which aligned with Atnafu (2016) who found that students with high risk propensity are 6 times more likely to have entrepreneurial intension or to go into self - employment. Ayalew \& Zeleke (2018) and Afolabi, Kareem, Okubanjo, Ogunbanjo, \& Aninkan (2017) also found a similar effect. The study also found that the development of self - employment will significantly improve the standard of living and growth of the economy which aligned with findings from other reseraches Tsvetkova, Partridge, \& Betz, 2016; Fields, 2014; Goetz \& Rupasingha, 2013; Bashir, Gebremedhin, \& Fletcher, 2011; Startienè \& Remeikiené, 2013). However, Goetz, Fleming, \& Rupasingha (2012) noted that self - employment may have little or no benefit for the local and national economy as it may just be a temporary measure for those laid off or job seekers till their condition improves.

\section{Conclusions}

From all the results obtained from this study, it is concluded that over half of the youth population in Ojo and Alimosho LGA of Lagos State are self - employed. Also, the perceptions of these youths about self - employment is high. In addition, self - employment increases local, regional and national income, reduce unempliyment through job provision and improve the standard of living of the citizens by lifting them out of poverty. Some of the challenges observed that affect self - employment include energy crises in Nigeria coupled with high and multiple levies and taxes which have combined to make the cost of doing business very excessive. Others are unavailability or inadequate enterpreneurial know - how due to outdated curriculum in the country and our national 
unwillingness to step up from policies that do not work. Lastly, it was concluded that only the promise of comfort from self - employment is associated with the development of self employment. It was found that risk taking as an attitude that significant affect the development of self - employment. The study also concluded that the development of self - employment will significantly improve the standard of living and growth of the economy

\section{Recommendations}

The following recommendations emanated from the findings of this study:

Firstly, government should make available well-equipped skills acquisition centres were youths can get trained on skills of their choice and government should also establish them after they might have gone through this training or make take - off funding available at affordable rate.

Secondly, Government should make sure that funds are made available to youths who are willing and ready to be self-employed and enhance power supply in order not to distort business climate.

Lastly the cost of doing business should be drastically reduced and create a conducive business environment so that locally made products can compete favourably so as to increase patronage

\section{References}

Abdulkareem, F. O., 2012. Nigeria Educational Policy and Entrepreneurship. Journal of Social Sciences, 9(2), pp. $75-78$.

Abdul-Kemi, I. Z., 2014. Entrepreneurship and Economic Development in Nigeria: Evidence from Small and Medium Scale Enterprises (SMEs) Financing. International Journal of Business and Social Sciences, 5(11(1)), pp. $215-230$

Abefe-Balogun, B. \& Nwankpa, N. T., 2012. Graduate Unemployment in Nigeria: Causes, Effect and Remedies. British Journal of Arts and Social Sciences, 5(2), pp. 142 - 154.

Afolabi, M. O. et al., 2017. Effect of Entrepreneurship Education on Self-Employment Initiatives among Nigerian Science \& Technology Students. Journal of Education and Practice, 8(15), pp. 44 - 51.

Aganga, S., 2013. Nigeria launches new self - employment scheme for undergraduates ]online]. Premium Times, 21 May, p. 135487.

Atnafu, A. M., 2016. Analysis on Determinants of Students Self Employment Intension in Newly Established Universities of Ethiopia: The Case of Dire Dawa University. Research on Humanities and Social Sciences, $6(3)$, pp. $25-41$.

Ayalew, M. \& Zeleke, S. A., 2018. Modeling the impact of entrepreneurial attitude on self-employment intention among engineering students in Ethiopia. Journal of Innovation and Entrepreneurship, 7(8), pp. 1 - 27.

Banerjee, A. V. \& Duflo, E., 2011. Poor Economics. New York: Public Affairs Press.

Bashir, S., Gebremedhin, T. \& Fletcher, J., 2011. An Analysis of the Role of Self-Employment in the Economic Development of the Rural Northeastern United States, West Virginia: Regional Research Institute.

Bjuggren, C. M., Johansson, D. \& Stenkula, M., 2010. Using Self-employment as Proxy for Entrepreneurship: Some Empirical Caveats, Stockholm: The Ratio Institute.

Bosma, S. K. \& Levie, A. A., 2012. Family firms and corporate culture: a case study from a less developed country (LDC). International Journal of Management and Enterprise Development, 3 (3), pp. 227 - 243.

Brown, S., Dietrich, M., Ortiz-Nuñez, A. \& Taylor, K., 2011. Self-employment and attitudes towards risk: Timing and unobserved heterogeneity. Journal of Economic Psychology, Volume 32, pp. 425 - 433.

Citizen Information, 2014. Monitoring by Delegates or by Peers? Joint Liability Loans Under Moral, s.1.: Hunter College Department of Economics.

Edelman, L. \& Yli-Renko, H., 2010. The impact of environment and entrepreneurial perceptions on venture creation efforts: Bridging the discovery and creation views of entrepreneurship. Entrepreneurship Theory and Practice, 34(5), pp. 833 - 856.

Eroke, S. A., 2014. Unemployment in Nigeria: Implication on the Gross Domestic Product (GDP) over the Years. International Journal Economics Resources, 2(1), pp. 66 - 71.

Fajana, S., 2004. Functioning of the Nigerian Labour Market. Lagos: Labofin and Company.

Fields, G. S., 2014. Self-employment and poverty in developing countries: , Germany: World of Labour (IZA).

Goetz, S. J., Fleming, D. A. \& Rupasingha, A., 2012. The Economic Impacts of Self-Employment. Journal of Agricultural and Applied Economics, 44(3), pp. 315 - 321.

Goetz, S. J. \& Rupasingha, A., 2013. Self-employment and local economic performance: Evidence from US counties. Papers in Regional Science, 92(1), pp. 141-161.

Idris, N. E., 2015. The current state of Nigerian economy. Bullion: Central Bank of Nigeria, 10(1).

ILO, 2007. Business Start-ups by the Unemployed - an Econometric Analysis Based on Firm Data. Labour Economics, 7(5), pp. 629 - 663.

Kigbu, D., 2007. National Youth Council Meeting. Calabar: Publishersss.

Lindh, I., 2017. An Entrepreneurial Mindset: Self-Regulating Mechanisms for Goal Attainment, Luleå: Luleå 
University of Technology, Graphic Production.

Longe, O., 2017. Graduate Unemployment in Nigeria: Causes, Consequences and Remediable Approaches. American International Journal of Contemporary Research, 7(4), pp. 63 - 74.

Margolis, D. N., 2014. By Choice and by Necessity: Entrepreneurship and Self-Employment in the Developing World, Bonn: Institute of Labor Economics - IZA.

McKenzie-Brown, P., 2012. Reflections on Communicative Language Teaching: A Course Book for Teaching English as a Foreign Language. Online: e-book.

Mijoč, J., Stanić, M. \& Horvat, J., 2016. Measuring attitudes in the self-employment intention model: methodological considerations. Croatian Operational Research Review, Volume 7, pp. 333 - 348.

Munk, R., 2016. Essays on Business Ownership and Self-Employment, s.1.: The Graduate School.

National Bureau of Statistics, 2011. 2011 Annual Socio - Economic Report, Abuja: National Bureau of Statistics.

Neneh, N. B., 2012. An exploratory study on entrepreneurial mindset in the small and medium enterprise (SME) sector: A South African perspective on fostering small and medium enterprise (SME) success. African Journal of Business Management, 6(9), pp. 3364 - 3372.

Nigeria Population Reference Bureau, 2007. Nigeria Statistics. [Online] Available at: http://www.prbdf.org/Countries/Nigeria.aspx [Accessed 22 February 2017].

Ogunrinola, I. O., 2011. Informal Self-Employment and Poverty Alleviation: Empirical Evidence from Motorcycle Taxi Riders in Nigeria. International Journal of Economics and Finance, 3(2), pp. 176 - 185.

Okafor, E. E., 2011. Youth Unemployment and Implications for Stability of Democracy in Nigeria. Journal of Sustainable Development in Africa, Volume 1, pp. 358 - 373.

Patterson, A., 2006. Business statistics: A first course.. Upper Saddle River, N.J: Prentice Hall.

Pollard, V. \& Wilson, E., 2013. The "Entrepreneurial Mindset" in Creative and Performing Arts Higher Education in Australia. Artivate: A Journal of Entrepreneurship in the Arts, 3(1), pp. 3 - 22.

Prince, O. J., 2016. Lagos State Self - Eemployment Programme. This Day Newpaper, 6 March, pp. 4 - 5.

Przepiorka, A. M., 2017. Psychological Determinants of Entrepreneurial Success and Life-Satisfaction. Current Psychology, Volume 36, pp. 304 - 315.

Reid, K. \& Ferguson, D. M., 2011. Enhancing the Entrepreneurial Mindset of Freshman Engineers. American Society for Engineering Education, p. online.

Robinson, P. B., Stimpson, D. V., Huefner, J. C. \& Hunt, H. K., 1991. An Attitude Approach to the Prediction of Entrepreneurship. Entrepreneurship Theory and Practice.

Simoes, N., Moreira, S. B. \& Crespo, N., 2013. Individual Determinants of Self-Employment Entry \{ What Do We Really Know?, Munich: Munich Personal RePEc Archive (MPRA).

Sola, K. F., 2016. Unemployment and Economic Growth in Nigeria. Journal of Economics and Sustainable Development, 5(4), pp. 161 - 169.

Somefun, O. A., 2014. Expanding Employment Opportunities for Nigerian Youths: The Self- Employment Imperative.[Online] Available

at: https://www.researchgate.net/publication/303545549 Expanding_Employment Opportunities for Nigeria $\underline{n}$ Youths The Self-Employment Imperative [Accessed 13 November 2018].

Startienè, G. \& Remeikienè, R., 2013. Evaluation of the impact of self-employment factors on self-employment duration in the country with transition economy: a Lithuanian case. Technological and Economic Development of Economy, 19(1), pp. 125 - 140.

Statistics Sweden, 2006. Registerbaserad arbetsmarknadsstatistik 2004, s.1.: AM0207.

Szaban, J. \& Skrzek-Lubasińska, M., 2018. Self-Employment and Entrepreneurship: A Theoretical Approach. Journal of Management and Business Administration. Central Europe, 26(2), pp. 89 - 120.

Tijani, M., 2016. NBS: Another 1.5m Nigerians became unemployed in 2016. The Cable [online], 21 May.

Tsvetkova, A., Partridge, M. \& Betz, M., 2016. Self-employment effects on regional growth: A bigger bang for a buck?, Munich: Munich Personal RePEc Archive (MPRA).

Ulrich, S., 2006. Stimulating Youth Entrepreneurship: Barriers and incentives to enterprise start-ups by young people, Geneva: International Labour Organization.

Wikipedia, 2014. Educating Tomorrow's Entrepreneurs Number Four Economic Reform Today. [Online].

Wioeniewska, M. Z., Tarczyñska, A. S. \& Papiashvili, T., 2015. The quality of the entrepreneurial attitudes among the students of the Faculty of Management at the University of Gdañsk. The pilot study. Journal of Management and Finance, 3(2), pp. 121 - 132.

World Youth Report, 2012. Enterprise-Based Youth Employment Policies, Strategies and Programmes.. Geneva: UN.

Youth Think, 2016. Putting the Young in Business: Policy Challenges for Youth Entrepreneurship, s.1.: Territorial Development Division. 